\title{
Evaluation antibacterial and antibiofilm activity of the antimicrobial peptide P34 against Staphylococcus aureus and Enterococcus faecalis
}

\author{
GÉSSICA A. COSTA ${ }^{1}$, FERNANDA C.P. ROSSATTO ${ }^{1}$, ALINE W. MEDEIROS ${ }^{1}$, ANA PAULA F. \\ CORREA $^{2}$, ADRIANO BRANDELLI ${ }^{2}$, ANA PAULA G. FRAZZON ${ }^{1}$ and AMANDA DE S. DA MOTTA ${ }^{1}$ \\ ${ }^{1}$ Programa de Pós-Graduação em Microbiologia Agrícola e do Ambiente, Instituto de Ciências Básicas da Saúde, \\ Universidade Federal do Rio Grande do Sul/UFRGS, Rua Sarmento Leite, 500, 90050-170 Porto Alegre, RS, Brazil \\ ${ }^{2}$ Instituto de Ciência e Tecnologia de Alimentos, Laboratório de Bioquímica e Microbiologia Aplicada, Universidade \\ Federal do Rio Grande do Sul/UFRGS, Avenida Bento Gonçalves, 9500, 91501-970 Porto Alegre, RS, Brazil
}

Manuscript received on March 10, 2016; accepted for publication on June 20, 2016

\begin{abstract}
The adhesion ability of bacteria to abiotic surfaces has important implications in food industries, because these organisms can survive for long periods through the biofilm formation. They can be transferred from one place to another in the industry causing contamination of the food processing environment. In this study, the antibacterial and antibiofilm activities of the antimicrobial peptide P34, characterized as a bacteriocinlike substance (BLS P34) were tested against planktonic and sessile cells of Staphylococcus aureus and Enterococcus faecalis isolated from foods. The BLS P34 showed inhibitory effect against all planktonic cells of E. faecalis. The inhibition of biofilm formation and the eradication of pre-formed biofilm were evaluated with the crystal violet assay and with the reduction of 3-bromide [4,5-dimethylthiazol-2-yl]2,5-diphenyltetrazolium. The BLS P34 promoted a reduction of percentage of adhered microbial cells on the surface, not being able to perform the complete elimination of biofilm formation. The metabolic activity of S. aureus biofilms decreased considerably between 41-95\%. However, E. faecalis cells showed up metabolically stimulated. The BLS P34 has the potential antibiofilm for the species $S$. aureus. Studies suggest more detailed approaches to a better understanding of the interactions between the antimicrobial and bacterial cells within the biofilm structure.
\end{abstract}

Key words: Biofilm, crystal violet, food industry, MTT assay, peptide P34.

\section{INTRODUCTION}

After the first report on biofilms by Zobell (1943), concern about them is still great, especially in the food, biomedical and environmental fields (Marques et al. 2007, Laird et al. 2011). Biofilms are multicellular structures formed by the attachment and aggregation

Correspondence to: Amanda de Souza da Motta

E-mail: amanda.motta@ufrgs.br of microorganisms followed by coating with a polysaccharide-rich extracellular matrix (Garrett et al. 2008). There are many advantages to an organism forming a biofilm, since these structures are more resistant to adverse environmental conditions compared to planktonic cells. Biofilms are resistance with makes their elimination from food processing environment a big challenge (Simões et al. 2006, Simões and Vieira 2009). 
Biofilms are a big problem in food sectors such as dairy processing, fresh produce, poultry and red meat processing (Chen et al. 2007), and usually are associated with serious hygiene problems causing deterioration and recontamination of the product (Gram et al. 2007). Several reports describe the persistence of some foodborne pathogens affecting the quality and safety of food products. Most outbreaks whose etiologic agents are transmitted by food seems to be associated with biofilms. In recent years, there have been a significant number of reports correlating the persistence of foodborne pathogens on food contact surfaces and the occurrence of biofilms (Simões and Vieira 2009, Yaron and Römling 2015, Bridier et al. 2015). Enterococcus spp. and Staphylococcus spp. are Gram positive pathogens associated with foodborne outbreaks. These bacteria have virulence factors, such as, aggregation substances, extracellular surface proteins, and ability to form biofilms (Chapman 2003, Fisher and Phillips 2009, Marinho et al. 2013). The E. faecalis was responsible for an outbreak with lenezolid resistance (LRE) in a hospital, affecting 13 people between 2004 and 2005 in Tennessee, USA (Kainer et al. 2007). Resistant bacteria may be transferred to humans through the food chain, and colonize the gastrointestinal tracts and/or may be able to transfer resistance genes to the resident microbiota (Fisher and Phillips 2009, Frazzon et al. 2009, Cassenego et al. 2011).

Staphylococcal foodborne disease (SFD) is one of the most common foodborne disease worldwide resulting from the contamination of food by preformed by Staphylococcus aureus enterotoxins (Kadariya et al. 2014). This species can produce many different enterotoxins (Schelin et al. 2011), which are stable to heat and have varying degrees of toxicity to the human body (Balaban and Rasooly 2000, Hennekinne et al. 2012). It is one of the most common causes of reported foodborne diseases in the United States (Kadariya et al. 2014). The ability of $S$. aureus to adhere and form biofilms improves their survival and growth in food processing plants, providing an additional physiological advantage as a causative agent of foodborne diseases (Herrera et al. 2007, Hennekinne et al. 2012).

Conventional cleaning and disinfection regimens may also contribute to inefficient biofilm control and its dissemination. Consequently, new control strategies are constantly emerging with the main incidence in the use of biological approaches (Simões et al. 2010). An alternative for the prevention and eradication of biofilm formation, would consider that antimicrobial peptides could be used. The antimicrobial peptide P34 was isolated and characterized as a bacteriocin-like substance (BLS) by Motta et al. (2007a) and the inhibitory activity was detected against Listeria monocytogenes, Bacillus cereus, and Salmonella Enteritidis (Motta et al. 2007b, 2008). Furthermore, some studies showed low cytotoxicity in eukaryotic cells and antiviral activity against pathogenic virus of domestic animals (Vaucher et al. 2010, Silva et al. 2014).

In this context, the objective of this study was to investigate the ability of E. faecalis and $S$. aureus isolates from food in Southern Brazil to form biofilm, and evaluate the potential antibiofilm activity of the BLS P34 produced by Bacillus sp. P34, a strain isolated from Piau-com-pinta (Leporinus sp.) a fish from Brazilian Amazon basin.

\section{MATERIALS AND METHODS}

\section{BACTERIAL STRAINS}

Eleven S. aureus strains obtained from fresh and frozen chicken meat samples and eleven $E$. faecalis strains isolated from food samples (potato, carrot, chicken salt, frozen chicken, ricotta and dairy products including colonial cheese) were evaluated. These isolates were previously identified by Martins et al. (2013) and Riboldi et al. (2009).

All isolates were revalued for colony morphology, Gram stain, catalase test, coagulase, 
and mannitol fermentation/or bile esculin test. The isolates were maintained in cryotubes containing $10 \%$ (v/v) skim milk and 20\% (v/v) glycerol, stored at $-20^{\circ} \mathrm{C}$. Bacterial cultures were grown in Brain Heart Infusion agar (BHI, Himedia) at $37^{\circ} \mathrm{C}$ for 24 $\mathrm{h}$, to obtain pure colonies before analysis.

\section{PRODUCTION AND PARTIAL PURIFICATION OF} BLS P34

The production and partial purification was determined in accordance with Motta et al. (2007a). For the production of BLS P34, Bacillus sp. P34 was grown in $100 \mathrm{ml} \mathrm{BHI} \mathrm{medium} \mathrm{at} 30^{\circ} \mathrm{C}$ in a rotary shaker at $180 \mathrm{rpm}$ (Motta and Brandelli 2008). After culturing for $24 \mathrm{~h}$, the cells were harvested by centrifugation at $10,000 \mathrm{~g}$ for $15 \mathrm{~min}$ at $4^{\circ} \mathrm{C}$. The filtrate was precipitated with ammonium sulfate at $20 \%(\mathrm{w} / \mathrm{v})$ saturation, and then dissolved in $10 \mathrm{mM}$ phosphate buffer $\mathrm{pH}$ 7.0. This solution was purified by gel filtration chromatography using a Sephadex G-100 column. The antimicrobial activity titre was determined by the serial twofold dilution method previously described by Mayr-Harting et al. (1972). Activity was defined as the reciprocal of the last serial dilution giving an inhibition zone and expressed as arbitrary unit (AU) per milliliter. The AU ml-1 was determined against Listeria monocytogenes ATCC 7644 as indicator strain due susceptibility to BLS P34. The fractions showing antimicrobial activity were pooled, sterilized through a $0.22 \mu \mathrm{m}$ filter (Millipore, Bedford, USA) and frozen stored (Motta et al. 2007a).

\section{ANTIMICROBIAL ACTIVITY OF BLS P34 AGAINST} PLANKTONIC CELLS OF Staphylococcus aureus AND Enterococcus faecalis

Antimicrobial activity was determined essentially as described by Motta and Brandelli (2002). An aliquot of $20 \mu 1$ of BLS P34 (1600 AU) was applied on surface of BHI agar plates previously inoculated with a swab submerged in suspensions of E. faecalis or $S$. aureus that corresponded to a
0.5 McFarland turbidity standard solution. The strain L. monocytogenes ATCC 7644 was used as a susceptible control. Plates were incubated at the optimal growth temperature of the test organisms $\left(37^{\circ} \mathrm{C}\right)$ and inhibitory zones were measured after $24 \mathrm{~h}$.

BIOFILM FORMATION BY Staphylococcus aureus AND Enterococcus faecalis

Quantitative determination of biofilm was determined by crystal violet assay (CV) in accordance with Stepanović et al. (2007) with some modifications. This methodology was chosen, for being the reference protocol to detection of biofilm formed by isolated food pathogens (Rodrigues et al. 2010, Marinho et al. 2013, Pinto et al. 2015). In summary, three to five colonies were suspended in $4 \mathrm{ml}$ of $0.85 \%$ (w/v) $\mathrm{NaCl}$ solution and compared with 0.5 McFarland scale (equivalent to $1.5 \times 10^{8}$ $\mathrm{CFU} \mathrm{ml}{ }^{-1}$ ). Twenty microliters of this solution was transferred to each well of the microplate. Later, 180 $\mu 1$ of Trypticase Soy Broth (TSB) containing $10 \mathrm{~g} \mathrm{l}^{-1}$ glucose was added to each well and the microplate was incubated at $37^{\circ} \mathrm{C}$ for $24 \mathrm{~h}$. After incubation the plate was washed with $0.85 \%(\mathrm{w} / \mathrm{v}) \mathrm{NaCl}$ solution for three times to remove non-adherent cells, $200 \mu 1$ of $100 \%$ methyl alcohol was added for $20 \mathrm{~min}$ to fix the adhered cells. The plate was dried at room temperature for $30 \mathrm{~min}$ and then $200 \mu \mathrm{l}$ of $0.5 \%$ crystal violet was added for $15 \mathrm{~min}$. After removing the dye solution and washing with sterile distilled water, the attached dye was solubilized with $0.5 \%(\mathrm{v} / \mathrm{v})$ ethanol and the optical density of the adherent biofilm was determined in a microtiter plate reader (Anthos Zenyth 200) with a filter of $450 \mathrm{~nm}$. All isolates were tested at least eight times in duplicate. Staphylococcus epidermidis ATCC 35984 was used as positive control, since this strain is a strong biofilm producer (Pinto et al. 2015). For interpretation of the biofilm results, the isolates were classified as non-producing, weak, moderate and strong-producing, based on the following optic 
density (OD) average values: OD (isolate) $\leq$ OD $($ control $)=$ non-biofilm-producing; OD $($ control $) \leq$ $\mathrm{OD}$ (isolate) $\leq 2 \mathrm{OD}$ (control) $=$ weak-producing; $2 \mathrm{OD}($ control $) \leq \mathrm{OD}$ (isolate) $\leq 4 \mathrm{OD}($ control $)=$ moderate-producing; 4OD (control) $\leq$ OD (isolate) $=$ strong-producing.

\section{DETERMINATION OF ANTIBIOFILM INHIBITORY} ACTIVITY BY BLS P34

Verification of antibiofilm activity was performed using the CV test and the test of the reduction of 3-[4,5-dimethyl-thiazol-2-yl]-2,5diphenyltetrazolium (MTT) simultaneously according Jadhav et al. (2013) with some modifications. The term "inhibiting" was used to refer to the surface that has been treated with the BLS P34 prior to deposition of biofilm forming microbial cells. The term "eradication" was used to refer to the treatment made of preformed biofilm with the BLS P34.

\section{Inhibition of initial cell attachment}

Solutions of BLS P34 (equivalent to $1600 \mathrm{AU}$ ) were prepared. One hundred microliters of each solution were added to individual wells of 96-well polystyrene microtiter plates for $4 \mathrm{~h}$. Equal volumes of sterile water were added as negative control. Subsequently, wells were washed three times with sterile distilled water and $100 \mu \mathrm{l}$ of the bacterial cultures (prepared as described above) were then added to the wells. The cultures were added into the wells in quadruplicate and sterile TSB was used as an additional control to confirm the sterility of the medium. The plates were incubated for $24 \mathrm{~h}$ at $37^{\circ} \mathrm{C}$. Biofilm formation was assessed using the $\mathrm{CV}$ assay and the metabolic activity of the cells incubated with BLS P34 was investigated using the MTT assay.

\section{Eradication of preformed biofilm}

Biofilms were allowed to be formed for $24 \mathrm{~h}$ prior to addition of BLS P34. Biofilm formation was achieved by transferring $100 \mu 1$ of bacterial culture (prepared as described above) into the wells of polystyrene microtitre plates in quadruplicate. The microtitre plates were incubated for $24 \mathrm{~h}$ at $37^{\circ} \mathrm{C}$ to allow cell attachment and initiate biofilm formation. Following incubation, the plate was washed with sterile distilled water to remove nonadhered cells and $100 \mu 1$ of BLS P34 solution (equivalent to $1600 \mathrm{AU}$ ) was added to each well. Equal volumes of sterile distilled water were added as negative control. After the treatment of preformed biofilms, the plates were incubated for 4 h. Following incubation, the biofilms were assessed using the CV assay and the MTT assay.

\section{QUANTIFICATION OF BIOFILM INHIBITION/ ERADICATION POTENTIAL BLS P34}

The mean absorbance at $450 \mathrm{~nm}$ was used for determining the percentage inhibition of biofilm formation caused by BLS P34 according to the following equation: Percentage inhibition $=100$ [\{ A450 nm experimental well with P34 / A450 $\mathrm{nm}$ control well without P34\} x 100] (Jadhav et al. 2013).

Percentage inhibition $=100-\left[\left\{\begin{array}{l}\text { A450 } \\ \mathrm{nm}\end{array}\right.\right.$ experimental well with P34 / A450 nm control well without P34\} x 100] (Jadhav et al. 2013).

\section{BIOFILM METABOLIC ACTIVITY ASSAY}

The evaluation of the metabolic activity of biofilm was determined by the reduction of MTT according to Denizot and Lang (1986) with some modifications. The MTT salt (Sigma-Aldrich, USA) was dissolved in phosphate buffered saline (PBS) to give a final concentration of $5 \mathrm{mg} \mathrm{ml}^{-1}$.

The culture medium or BLS P34 were carefully removed and the wells were washed five times with $0.85 \%(\mathrm{w} / \mathrm{v}) \mathrm{NaCl}$ solution and air-dried. One 
hundred microliters of MTT solution were pipetted into each well and incubated for $3 \mathrm{~h}$ at $37^{\circ} \mathrm{C}$. The insoluble purple formazan (obtained by enzymatic hydrolysis of MTT by the dehydrogenase enzyme found in living cells) was further dissolved in 100 $\mu 1$ of dimethyl sulphoxide (DMSO; Sigma-Aldrich, USA). The absorbance was then measured at 570 nm using a microplate reader (Anthos Zenyth 200).

\section{STATISTICAL ANALYSIS}

All experiments were performed at least in triplicates and standard deviation from the mean was calculated. Effect of BLS P34 on biofilm formation was analyzed using One-way Anova by Statistica 10.0 software. Values were considered significantly different each other at $\mathrm{P}<0.05$.

\section{RESULTS}

\section{ANTIMICROBIAL ACTIVITY AGAINST}

PLANKTONIC CELLS OF Staphylococcus aureus AND

Enterococcus faecalis

The antimicrobial activity of BLS P34 against $S$. aureus and E. faecalis are presented in Table I. Five $S$. aureus strains showed inhibition zones $\geq 10.0$ $\mathrm{mm}$, while other strains were not sensitive to BLS P34 (Table I). The BLS P34 was more effective to inhibit $E$. faecalis isolates, since all isolates showed inhibition zones $\geq 12.0 \mathrm{~mm}$. For the indicator strain L. monocytogenes ATCC 7644 used as a positive control, an inhibition zone of $13.6 \mathrm{~mm}$ was observed (Table I).

BIOFILM FORMATION BY Staphylococcus aureus AND Enterococcus faecalis

All isolates tested were biofilm producers. Among the eleven isolates of $S$. aureus evaluated, seven $(63.3 \%)$ were classified as strong biofilm formers and four $(36.4 \%)$ as moderate formers. Six isolates of E. faecalis $(54.5 \%)$ were showed as strong biofilm formers and five $(45.4 \%)$ as moderate formers (Table II).
DETERMINATION OF BIOFILM INHIBITORY ACTIVITY OF BLS P34

\section{Inhibition of initial cell adhesion}

The BLS P34 caused lower inhibition of initial cell adhesion in E. faecalis strains when compared with the $S$. aureus strains (Table III). The highest inhibition of cell adhesion (46.9\%) was observed against $S$. aureus F4-1 strain. For other isolates from this group, the inhibition percentage of adhesion ranged from $8.3 \%$ to $22.3 \%$ (Table III). The E. faecalis $\mathrm{C}-11$ showed the highest inhibition percentage of adhesion (31.4\%). For the control $S$. epidermidis ATCC 35984 strain, the BLS P34 was able of providing an inhibition of $9.2 \%$ (Table III).

\section{Eradication of preformed biofilm}

When the BLS P34 was applied over the preformed biofilm, $S$. aureus F4-1 strain was the most sensitive (55.7\%), similarly to that observed in the previous evaluation. For other isolates of $S$. aureus, the percentage of eradication ranged from $1.1 \%$ to $17.6 \%$, excepting for the F2-4 strain that exhibited a negative value (Table III). Only three E. faecalis namely $\mathrm{C} 8, \mathrm{E} 2$ and G4, suffered eradication, with results of $2.8 \%, 6.9 \%$ and $7.5 \%$ respectively. However, these results were lower when compared to the treatment before the biofilm formation. The other strains showed negative percentage of eradication, which suggests a stimulation originated by the presence of the antimicrobial substance (Table III). The statistical analysis indicates that different conditions of BLS P34 treatment changes the percentage of adhered cells in case of $E$. faecalis group $(\mathrm{P}<0.05)$. However, for the $S$. aureus group, this difference was not observed. The control $S$. epidermidis ATCC 35984 strain shows $7.5 \%$ of eradication. 
TABLE I

Antimicrobial activity spectrum of BLS P34 against planktonic cells of Staphylococcus aureus and Enterococcus faecalis at $37^{\circ} \mathrm{C}$.

\begin{tabular}{lclc}
\hline Indicator organism & Inhibition zone $(\mathbf{m m})$ & Indicator organism & Inhibition zone (mm) \\
\hline Control strain & & & \\
L. monocytogenes ATCC 7644 & & & 13.6 \\
\hline S. aureus strains & & E. faecalis strains & 12.0 \\
\hline F -2-1 & 0 & A-8 (colonial cheese) & 12.2 \\
F -2-3 & 11.0 & C-8 (carrot) & 13.5 \\
F -2-4 & 0 & C-11 (potato) & 12.0 \\
F -3-3 & 12.2 & E-2 (potato) & 12.5 \\
F -4-1 & 13.0 & E-3 (potato) & 13.0 \\
F -5-1 & 11.3 & E-4 (potato) & 13.3 \\
F -5-2 & 0 & E-7 (chicken salt) & 12.3 \\
F -5-3 & 10.0 & G-2 (ricota) & 12.5 \\
F -5-4 & 0 & G-4 (frozen chicken) & 12.5 \\
F -5-5 & 0 & G-6 (colonial cheese) & 12.0 \\
F -8 -3 & 0 & G-8 (mozzarela cheese) & \\
\hline
\end{tabular}

TABLE II

Classification Staphylococcus aureus and Enterococcus faecalis isolated from food samples according to their ability to form biofilm at $37^{\circ} \mathrm{C}$.

\begin{tabular}{llll}
\hline Indicator organism & Classification & $\begin{array}{l}\text { Indicator } \\
\text { organism }\end{array}$ & Classification \\
\hline
\end{tabular}

Control strain

S. epidermidis ATCC 35984

S

\begin{tabular}{|c|c|c|c|c|}
\hline S. aureus strains & \multicolumn{4}{|c|}{ E. faecalis strains } \\
\hline F 2-1 & \multirow{2}{*}{$\mathrm{M}$} & \multicolumn{2}{|c|}{ A-8 } & \\
\hline F 2-3 & & \multicolumn{2}{|r|}{ C-8 } & $\begin{array}{l}\mathrm{M} \\
\mathrm{C}\end{array}$ \\
\hline F 2-4 & $\begin{array}{l}\mathrm{S} \\
\mathrm{S}\end{array}$ & \multicolumn{2}{|r|}{ C-11 } & S \\
\hline F 3-3 & $\begin{array}{l}\mathrm{S} \\
\mathrm{S}\end{array}$ & \multicolumn{2}{|r|}{ E-2 } & $\begin{array}{l}M \\
M\end{array}$ \\
\hline F 4-1 & $\mathrm{S}$ & \multicolumn{2}{|r|}{ E-3 } & $\mathrm{S}$ \\
\hline F 5-1 & $\mathrm{S}$ & \multicolumn{2}{|r|}{ E-4 } & M \\
\hline F 5-2 & $\mathrm{S}$ & \multicolumn{2}{|r|}{ E-7 } & $\mathrm{S}$ \\
\hline F $5-3$ & $\mathrm{~S}$ & \multicolumn{2}{|r|}{ G-2 } & $\mathrm{S}$ \\
\hline F 5-4 & M & \multicolumn{2}{|r|}{ G-4 } & M \\
\hline F 5-5 & M & \multicolumn{2}{|r|}{ G-6 } & $\mathrm{S}$ \\
\hline F 8-3 & M & \multicolumn{2}{|r|}{ G-8 } & $\mathrm{S}$ \\
\hline Isolates (n) & Strong & Moderate & Weak & Non Producer \\
\hline 22 & $13(59.09 \%)$ & $11(50 \%)$ & 0 & 0 \\
\hline
\end{tabular}

S: Strog producer; M: Moderate producer. A biofilm was formed for $24 \mathrm{~h}$ in control conditions. The biofilm was assayed with the CV method. 
TABLE III

Percentage of antibiofilm potential of BLS P34 against Staphylococcus aureus and Enterococcus faecalis biofilms using the CV assay.

\begin{tabular}{cccccc}
\hline Bacterial group & \multicolumn{2}{c}{ Treatment } & Bacterial group & \multicolumn{2}{c}{ Treatment } \\
\hline Staphylococcus aureus & A & B & Enterococcus faecalis & A & B \\
\hline F 2-1 & 22.2 & 45.7 & A-8 & 2.4 & -2.8 \\
F 2-3 & 15.4 & 6.9 & C-8 & 22.4 & 2.8 \\
F 2-4 & 18.8 & -1.8 & C-11 & 31.4 & -7.2 \\
F 3-3 & 19.8 & 15.1 & E-2 & 23.5 & 6.9 \\
F 4-1 & 46.9 & 55.7 & E-3 & 18.6 & -5.8 \\
F 5-1 & 22.3 & 5.3 & E-4 & 13.1 & -5.0 \\
F 5-2 & 14.6 & 9.0 & E-7 & 29.4 & -6.0 \\
F 5-3 & 40.5 & 9.6 & G-2 & 23.5 & -4.6 \\
F 5-4 & 9.3 & 8.6 & G-4 & 13.4 & 7.5 \\
F 5-5 & 8.8 & 1.5 & G-6 & 30.0 & -7.5 \\
F 8-3 & 12.2 & 17.6 & G-8 & 6.6 & -1.6 \\
\hline
\end{tabular}

\section{Control strain}

Each strain was individually evaluated and the values are expressed as percentage of inhibition of initial cell adhesion (treatment A) or eradication of preformed biofilm (treatment B) evaluated using the CV assay. Negative values indicate stimulation on biofilm formation.

METABOLIC ACTIVITY OF THE BIOFILMS FORMED BY Staphylococcus aureus AND Enterococcus faecalis TREATED WITH BLS P34

During the initial cell adhesion assay, S. aureus isolates showed reduced metabolic activity, with percentages between $41 \%$ and $95 \%$, excepting for the isolate F3-3 that exhibited a negative result indicating increased metabolic activity (Table IV). In the assay of eradication of preformed biofilm, the $S$. aureus strains showed metabolic inhibition between $14 \%$ and $94 \%$. Only the strain F2-4 exhibited stimulation on metabolic activity in this treatment (-38\%).

All E. faecalis strains showed negative results in both treatments. Although in the CV assay demonstrated inhibition of some strains, the other microbial cells that were adhered to the wells were metabolically active and stimulated when compared to the control group (Table IV). Only E. faecalis strains showed a statistically significant difference when treated with BLS P34 $(\mathrm{P}<0.05)$. This behavior is probably associated to a higher metabolic stimulation in the treatment for inhibition of cell adhesion. The control $S$. epidermidis ATCC 35984 strain showed metabolism inhibition values of $42 \%$ and $51 \%$ for the initial cell adhesion and eradication of preformed biofilm tests, respectively.

\section{DISCUSSION}

Foodborne diseases cover a wide range of symptons and are triggered by agents that are consumed along with food. Food contamination may occur at any stage of the production process and can result in contamination of the processing environment (Simões et al. 2010, Srey et al. 2013). It has been recognized that biofilms are a frequent source for 
TABLE IV

Effect of BLS P34 on metabolic activity of biofilm cells of Staphylococcus aureus and Enterococcus faecalis at $37^{\circ} \mathrm{C}$.

\begin{tabular}{|c|c|c|c|c|c|}
\hline \multirow{2}{*}{$\begin{array}{c}\text { Bacterial group } \\
\text { Staphylococcus aureus }\end{array}$} & \multicolumn{2}{|c|}{ Treatment } & \multirow{2}{*}{$\begin{array}{c}\text { Bacterial group } \\
\text { Enterococcus faecalis }\end{array}$} & \multicolumn{2}{|c|}{ Treatment } \\
\hline & $\mathbf{A}$ & B & & $\mathbf{A}$ & B \\
\hline F 2-1 & 46 & 59 & A-8 & -248 & -27 \\
\hline F 2-3 & 95 & 86 & C-8 & -143 & -23 \\
\hline F 2-4 & 81 & -38 & C-11 & -222 & -2 \\
\hline F 3-3 & -97 & 14 & E-2 & -155 & -17 \\
\hline F 4-1 & 46 & 70 & E-3 & -348 & -32 \\
\hline F 5-1 & 61 & 71 & E-4 & -135 & -17 \\
\hline F 5-2 & 66 & 64 & E-7 & -388 & -29 \\
\hline F 5-3 & 41 & 23 & G-2 & -382 & -27 \\
\hline F 5-4 & 44 & 88 & G-4 & -89 & -22 \\
\hline F 5-5 & 93 & 94 & G-6 & -135 & -25 \\
\hline F 8-3 & 64 & 90 & G-8 & -52 & -23 \\
\hline
\end{tabular}

\section{Control strain}

Each strain was individually evaluated and the values are expressed in percentage of inhibition of metabolic activity. Negative values indicate stimulation of cellular metabolic activity. A: Inhibition of metabolic activity on the initial cell adhesion; B: Inhibition of metabolic activity on the eradication of the preformed biofilm.

infections and almost $80 \%$ of persistent bacterial infections in the United States were found to be associated with biofilms (Janssens et al. 2008).

In the present study, all food strains of $S$. aureus and E. faecalis were able to form biofilms. In general, Staphylococcus sp. isolates have a significant incidence of biofilm formation in the food industry (Ferreira et al. 2014, Pinto et al. 2015). Several mechanisms are involved in the process to establish the biofilm on the surface, like the presence of genes involved in the adhesion process and extracellular polymeric substance (EPS) production (Ferreira et al. 2014). Moreover, the ability of $S$. aureus isolated from industrial surfaces to form biofilm depends on the environmental conditions. The hygienic condition of food handlers is also associated with the propagation of $S$. aureus biofilm producer (Gutiérrez et al. 2012, Souza et al. 2014, Di Ciccio et al. 2015).

Several authors have reported E. faecalis strains isolated from food samples with ability to form biofilms (Medeiros et al. 2014, Jahan and Holley 2014, Fernandes et al. 2015). Apparently, the biofilm formation by this bacterial species is influenced by several aspects, such as temperature, exposure to nutrients and sanitizers, and surface characteristics (Marinho et al. 2013, Fernandes et al. 2015). According to Jahan and Holley (2014), their capacity to exchange genetic information by conjugation, contributes to the resistance and dissemination of $E$. faecalis in food.

Planktonic cells are important for the quick proliferation and dissemination of microorganisms to new surfaces, while the sessile cells are considered a chronic factor because of surface adhesion. It is 
generally accepted and well documented that cells within a biofilm are more resistant to biocides than their planktonic counterparts (Houdt and Michiels 2010, Simões et al. 2010). The antimicrobial potential of BLS P34 against planktonic cells was explored in this work, and it was observed that the substance was able to inhibit the growth of five $S$. aureus strains. However, all strains of E. faecalis were sensitive to the action of this antimicrobial in planktonic condition. Contrary to these results, Motta et al. (2007a) evaluated the same antimicrobial peptide against $S$. aureus and E. faecalis and found no inhibitory action. This discrepancy can be associated with the fact that the effectiveness of antimicrobial peptides is often dependable on its concentration and degree of purification, as well as concentration of the indicator strain and culture medium (Lisboa et al. 2006, Motta and Brandelli 2008). Lisboa et al. (2006) evaluated an antimicrobial peptide produced by Bacillus amyloliquefaciens at the concentration of $256 \mathrm{AU}$ against a clinical isolate of E. faecalis and observed an inhibitory zone of $14 \mathrm{~mm}$. In a study realized by Motta et al. (2008), using the transmission electron microscopy against planktonic cells of L. monocytogenes, the authors report that cells treated with BLS P34 showed vesiculation of the protoplasm, pore formation and disintegration of the cells. It is possible that the antimicrobial activity against the isolates of this study has occurred in a similar way, because both are Gram-positive.

In recent years, the use of antimicrobial peptides on surfaces to prevent microbial adhesion proves to be an interesting approach in food processing facilities (Massani et al. 2008, Aminov 2010, Héquet et al. 2011). Bioconservatives molecules such as nisin, pediocin and lauricidin have potential for biofilm control in processing facilities. (Mahdavi et al. 2007, Garcia-Almendarez et al. 2008). Some antimicrobial molecules can make the surface less hydrophobic, and thus, reduce cell adhesion. This attribute suggests its application to control microbial adhesion and helping in the destabilization of biofilms (Gomes and Nitschke 2012).

Although the mechanism of action of BLS P34 against planktonic cells is not fully elucidated, this study provides a new application approach of the substance, providing information about the antibiofilm potential, never studied before. The CV assay showed that BLS P34 was able to eliminate some of the planktonic cells that form the biofilm. Likely these cells by coming in contact with the conditioned surface with the antimicrobial, were reduced in number, influencing the adhesion capacity. Therefore, the conditioning of the surface became less favorable to cell adhesion.

To provide a better understanding on the effect of BLS P34 on biofilms is necessary the correlation between the results of $\mathrm{CV}$ technique and the MTT assay. Although the CV assay serves as an indicator of adhesion, it does not reveal the metabolic status of the cells. MTT assay is a tetrazolium salt, which in the presence of metabolically active cells is reduced into a product that can be measured colorimetrically, serving as a respiratory indicator of live cells (Krom et al. 2007). In biofilms, the MTT assay was used as an indicator of attached viable cells, while CV stains both viable and nonviable cells that may be attached (Kouidhi et al. 2010).

The metabolic activity of biofilms was theoretically controlled, by environmental conditions at the surface and expression of specific genes induced by adhesion (O'Toole and Kolter 1998). The low cellular metabolism provides resistance to antimicrobials that act during bacterial growth phase. This ability to survive the antimicrobial treatment at slow growth rates ensures the presence of persistent cells (Lewis 2012). The results of the MTT assay confirmed that the BLS P34 inhibited the metabolic activity of biofilms formed by $S$. aureus strains. The decrease in cell 
metabolism occurs because most antimicrobial peptides work by interacting with the bacterial cell surface, followed by disruption of cellular integrity (Nawrocki et al. 2014). In a previous study, the BLS P34 showed a similar effect on the bacterial wall of L. monocytogenes ATCC 7644 (Motta et al. 2008).

The results of MTT assay also showed that E. faecalis biofilms were metabolically active. These strains were genotypically characterized by Medeiros et al. (2014) that found the presence of gelatinase ( $\mathrm{gelE}$ ) and cytolysin (cylA) genes. Such virulence factors and phenotypic characteristics of each strain may be associated with metabolic stimulation. Moreover, it is possible that the cell stimulation has occurred due to the antimicrobial molecule has been inactivated and used as a substrate for the cell. Del Papa et al. (2007) report that the degradation of antimicrobial peptides (AMPs) by proteases is a mechanism of resistance found in many Gram-positive species, including $E$. faecalis and $S$. aureus. AMP-degrading proteases generally have broad substrate specificity, are typically found in mammalian pathogens, and include both metallopeptidases and cysteine proteases. Furthermore, Motta et al. (2007b) evaluate the residual activity of the BLS P34 treated with proteolytic enzymes like trypsin, papain, pronase $\mathrm{E}$ and proteinase $\mathrm{K}$, and they found loss of antimicrobial potential. The inefficiency to inhibit cellular metabolism of E. faecalis using the BLS P34 confirms that biofilms are more resistant to antimicrobial agents than planktonic cells.

The results of this study demonstrated that the BLS P34 has the potential to prevent and eradicate the biofilm formation by $S$. aureus and E. faecalis. However, the substance was more effective to reduce the metabolic activity of bacterial cells in $S$. aureus biofilms. These results also indicate the antimicrobial potential of BLS P34 against planktonic cells of $S$. aureus and E. faecalis, which can be useful for many applications and must be better explored.

\section{ACKNOWLEDGMENTS}

This work was supported by Conselho Nacional de Desenvolvimento Científico e Tecnológico (CNPq, Brazil).

\section{REFERENCES}

AMINOV RI. 2010. A brief history of the antibiotic era: Lessons learned and challenges for the future. Front Microbiol 1: 1-7.

BALABAN N AND RASOOLY A. 2000. Staphylococcal enterotoxins. Int J Food Microbiol 61: 1-10.

BRIDIER A, SANCHEZ-VIZUETE P, GUILBAUD M, PIARD JC, NAÏTALI M AND BRIANDET R. 2015. Biofilm-associated persistence of food-borne pathogens. Food Microbiol 45: 167-178.

CASSENEGO APV, D'AZEVEDO PA, RIBEIRO AML, FRAZZON J, VAN DER SAND ST AND FRAZZON APG. 2011. Species distribution and antimicrobial susceptibility of enterococci isolated from broilers infected experimentally with Eimeria spp. and fed with diets containing different supplements. Braz J Microbiol 42: 480-488.

CHAPMAN JS. 2003. Disinfectant resistance mechanisms, cross-resistance, and co-resistance. Int Biodeter Biodegrad 51: 271-276.

CHEN J, ROSSMAN ML AND PAWAR DM. 2007. Attachment of enterohemorragic Escherichia coli to the surface of beef and a culture medium. LWT - Food Sci Technol 40: 249-254.

DEL PAPA MF, HANCOCK LE, THOMAS VC AND PEREGO M. 2007. Full activation of Enterococcus faecalis gelatinase by a $\mathrm{C}$-terminal proteolytic cleavage. $\mathrm{J}$ Bacteriol 189: 8835-8843.

DENIZOT F AND LANG R. 1986. Rapid colorimetric assay for cell growth and survival. Modifications to the tetrazolium dye procedure giving improved sensitivity and reliability. J Immunol Meth 89: 271-277.

DI CICCIO P, VERGARA A, FESTINO AR, PALUDI D, ZANARDI E, GHIDINI S AND IANIERI A. 2015. Biofilm formation by Staphylococcus aureus on food contact surfaces: Relationship with temperature and cell surface hydrophobicity. Food Control 50: 930-936.

FERNANDES MS, YORIKA KD AND YOSHITERU KA. 2015. Behavior of Listeria monocytogenes in a multi-species biofilm with Enterococcus faecalis and Enterococcus faecium and control through sanitation procedures. Int J Food Microbiol 200: 5-12. 
FERREIRA AA, TETTE PAS, MENDONÇA RCS, SOARES AS AND DE CARVALHO MM. 2014. Detection of exopolysaccharide production and biofilm-related genes in Staphylococcus spp. isolated from a poultry processing plant. Food Sci Technol (Campinas) 34: 710-716.

FISHER K AND PHILLIPS C. 2009. The ecology, epidemiology and virulence of Enterococcus. Microbiology 155: 1749-1757.

FRAZZON APG, GAMA BA, HERMES V, BIERHALS CG, PEREIRA RI, GUEDES AG, D'AZEVEDO PA AND FRAZZON J. 2009. Prevalence of antimicrobial resistance and molecular characterization of tetracycline resistance mediated by tet $(\mathrm{M})$ and tet $(\mathrm{L})$ genes in Enterococcus spp. isolated from food in Southern Brazil. World J Microbiol Biotechnol 26: 365-370.

GARCIA-ALMENDAREZ BE, CANN IKO, MARTIN SE, GUERRERO-LEGARRETA I AND REGALADO C. 2008. Effect of Lactococcus lactis UQ2 and its bacteriocin on Listeria monocytogenes biofilms. Food Control 19: 670-680.

GARRETT TR, BHAKOO M AND ZHANG Z. 2008. Bacterial adhesion and biofilms on surfaces. Prog Nat Sci 18: 1049-1056.

GOMES MZV AND NITSCHKE M. 2012. Evaluation of rhamnolipid and surfactin to reduce the adhesion and remove biofilms of individual and mixed cultures of food pathogenic bacteria. Food Control 25: 441-447.

GRAM L, BAGGE-RAVN D, NG YY, GYMOESE P AND VOGEL BF. 2007. Influence of food soiling matrix on cleaning and disinfection efficiency on surface attached Listeria monocytogenes. Food Control 18: 1165-1171.

GUTIÉRREZ D, DELGADO S, VÁZQUEZ-SÁNCHEZ D, MARTÍNEZ B, CABO ML, RODRÍGUEZ A, HERRERA JJ AND GARCÍA P. 2012. Incidence of Staphylococcus aureus and analysis of associated bacterial communities on food Industry surfaces. Appl Environ Microbiol 78: 8547-8554.

HENNEKINNE JA, BUYSER ML AND DRAGACCI S. 2012. Staphylococcus aureus and its food poisoning toxins: characterization and outbreak investigation. FEMS Microbiol Rev 4: 815-836.

HÉQUET A, HUMBLOT V, BERJEAUD JM AND PRADIER CM. 2011. Optimized grafting of antimicrobial peptides on stainless steel surface and biofilm resistance tests. Colloids Surf B Biointerfaces 84: 301-309.

HERRERA JJR, CABO ML, GONZÁLEZ A, PAZOS I AND PASTORIZA L. 2007. Adhesion and detachment kinetics of several strains of Staphylococcus aureus subsp. aureus under three different experimental conditions. Food Microbiol 24: 585-591.

HOUDT RV AND MICHIELS CW. 2010. Biofilm formation and the food industry, a focus on the bacterial outer surface. J Appl Microbiol 109: 1117-1131.
JADHAV S, SHAH R, BHAVE M AND PALOMBO EA. 2013. Inhibitory activity of yarrow essential oil on Listeria planktonic cells and biofilms. Food Control 29: 125-130.

JAHAN M AND HOLLEY RA. 2014. Incidence of virulence factors in enterococci from raw and fermented meat and biofilm forming capacity at $25^{\circ} \mathrm{C}$ and $37^{\circ} \mathrm{C}$. Int $\mathrm{J}$ Food Microbiol 170: 65-69.

JANSSENS JCA ET AL. 2008. Brominated furanones inhibit biofilm formation by Salmonella enterica serovar typhimurium. Appl Environ Microbiol 74: 6639-6648.

KADARIYA J, SMITH TC AND THAPALIYA D. 2014. Staphylococcus aureus and Staphylococcal Food-Borne Disease: An ongoing challenge in public health. BioMed Res Int 2014: 1-9.

KAINER MA, DEVASIA RA, JONES TF, SIMMONS BP, MELTON K, CHOW S, BROYLES J, MOORE KL, CRAIG AS AND SCHAFFNER W. 2007. Response to emerging infection leading to outbreak of LinezolidResistant Enterococci. Emerg Infect Dis 13: 1024-1030.

KOUIDHI B, ZMANTAR T AND BAKHROUF A. 2010. Anti-cariogenic and anti-biofilms activity of Tunisian propolis extract and its potential protective effect against cancer cells proliferation. Anaerobe 16: 566-571.

KROM BP, COHEN JB, MCELHANEY FESER GE AND CIHLAR RL. 2007. Optimized candidal biofilm microtiter assay. J Microbiol Meth 68: 421-423.

LAIRD K, ARMIAGE D AND PHILLIPS C. 2011. Reduction of surface contamination and biofilms of Enterococcus sp. and Staphylococcus aureus using a citrus-based vapour. J Hosp Infect 80: 61-66.

LEWIS K. 2012. Persister cells: molecular mechanisms related to antibiotic tolerance. Handb Exp Pharmacol 211: 121-133.

LISBOA MP, BONATTO D, BIZANI D, HENRIQUES JÁ AND BRANDELLI A. 2006. Characterization of a bacteriocin-like substance produced by Bacillus amyloliquefaciens isolated from the Brazilian Atlantic forest. Int Microbiol 9: 111-118.

MAHDAVI M, JALALI M AND KERMANSHAHI RK. 2007. The effect of nisin on biofilm forming foodborne bacteria using microtiter plate method. Res Pharm Sci 2: 113-118.

MARINHO AR, MARTINS PD, DITMER EM, D'AZEVEDO PA, FRAZZON J, VAN DER SAND ST AND FRAZZON APG. 2013. Biofilm formation on polystyrene under different temperatures by antibiotic resistant Enterococcus faecalis and Enterococcus faecium isolated from food. Braz J Microbiol 44: 423-426.

MARQUES SC, REZENDE JGOS, ALVES LAF, SILVA BC, ALVES E, DE ABREU LR AND PICCOLI RH. 2007. Formation of biofilms by Staphylococcus aureus on stainless steel and glass surfaces and its resistance to some selected chemical sanitizers. Braz J Microbiol 38: 538-543. 
MARTINS PD, DE ALMEIDA TT, BASSO AP, DE MOURA TM, FRAZZON J, TONDO EC AND FRAZZON AP. 2013. Coagulase-positive staphylococci isolated from chicken meat: pathogenic potential and vancomycin resistance. Foodborne Pathog Dis 10: 771-776.

MASSANI MB, FERNANDEZ MR, ARIOSTI A, EISENBERG P AND VIGNOLO G. 2008. Development and characterization of an active polyethylene film containing Lactobacillus curvatus CRL705 bacteriocins. Food Addit Contam 25: 1424-1430.

MAYR-HARTING A, HEDJES AJ AND BERKELEY CW. 1972. Methods for studying bacteriocins. In: Norris JB and Ribbons D (Eds), Methods in Microbiology. Academic, New York, p. 315-412.

MEDEIROS AW, PEREIRA RI, OLIVEIRA DV, MARTINS PD, D'AZEVEDO PA, VAN DER SAND S, FRAZZON J AND FRAZZON APG. 2014. Molecular detection of virulence factors among food and clinical Enterococcus faecalis strains in South Brazil. Braz J Microbiol 45: 327332.

MOTTA AS AND BRANDELLI A. 2002. Characterization of an antimicrobial peptide produced by Brevibacterium linens. J Appl Microbiol 92: 63-70.

MOTTA AS AND BRANDELLI A. 2008. Evaluation of environmental conditions for production of bacteriocinlike substance by Bacillus sp. strain P34. World J Microbiol Biotechnol 24: 641-646.

MOTTA AS, CANNAVAN FS, TSAI SM AND BRANDELLI A. 2007a. Characterization of a broad range antibacterial substance from a new Bacillus species isolated from Amazon basin. Arch Microbiol 188: 367-375.

MOTTAAS, FLORES FS, SOUTO AAAND BRANDELLI A. 2008. Antibacterial activity of a bacteriocin-like substance produced by Bacillus sp. P34 that targets the bacterial cell envelope. Anton Leeuw 93: 275-284.

MOTTA AS, LORENZINI DM AND BRANDELLI A. $2007 \mathrm{~b}$. Purification and partial characterization of an antimicrobial peptide produced by a novel Bacillus sp. isolated from the Amazon Basin. Curr Microbiol 54: 282-286.

NAWROCKI KL, CRISPELL EK AND MCBRIDE SM. 2014. Antimicrobial peptide resistance mechanisms of Gram-positive bacteria. Antibiotics 3: 461-492.

O'TOOLE GA AND KOLTER R. 1998. The initiation of biofilm formation in Pseudomonas fluorescens WCS365 proceeds via multiple, convergent signaling pathways: a genetic analysis. Mol Microbiol 28: 449-461.

PINTO JB, ROSSATTO FCP, MARTINS PD AND FRAZZON APG. 2015. Genetic relationships and virulence factors in Staphylococcus aureus isolated from raw poultry in South Brazil. Ann Microbiol 65: 1933-1940.

RIBOLDI GP, FRAZZON J, D'AZEVEDO PA AND FRAZZON APG. 2009. Antimicrobial resistance profile of
Enterococcus spp. isolated from food in Southern Brazil. Braz J Microbiol 40: 125-128.

RODRIGUES LB, DOS SANTOS LR, TAGLIARI VZ, RIZZO NN, TRENHAGO G, DE OLIVEIRAAP, GOETZ F AND NASCIMENTO VP. 2010. Quantification of biofilm production on polystyrene by Listeria, Escherichia coli and Staphylococcus aureus isolated from a poultry slaughterhouse. Braz J Microbiol 41: 1082-1085.

SCHELIN J, WALLIN-CARLQUIST N, COHN MT, LINDQVIST R, BARKER GC AND RADSTROM P. 2011. The formation of Staphylococcus aureus enterotoxin in food enviroments and advanced in risk assessment. Virulence 2: 580-592.

SILVA DS, DE CASTRO CC, SILVA FS, SANT'ANNA V, VARGAS GD, DE LIMA M, FISCHER G, BRANDELLI A, MOTTA AS AND HÜBNER SO. 2014. Antiviral activity of a Bacillus sp. P34 peptide against pathogenic viroses of domestic animals. Braz J Microbiol 45: 10891094.

SIMÕES M, SIMÕES LC, MACHADO I, PEREIRA MO AND VIEIRA MJ. 2006. Control of flow-generated biofilms using surfactants - evidence of resistance and recovery. Food Bioprod Process 84: 338-345.

SIMÕES M, SIMÕES LC AND VIEIRA MJ. 2010. A review of current and emergent biofilm control strategies. LWT Food Sci Technol 43: 573-583.

SIMÕES M AND VIEIRA MJ. 2009. Persister cells in Pseudomonas fluorescens biofilms treated with a biocide. In: Proceedings of the international conference processes in biofilms: Fundamentals to applications. Davis, CA, USA, p. 58-62.

SOUZA EL, MEIRA QGS, BARBOSA IM, ATHAYDE AJAA, DA CONCEIÇÃO ML AND SIQUEIRA JÚNIOR JP. 2014. Biofilm formation by Staphylococcus aureus from food contact surfaces in a meat-based broth and sensitivity to sanitizers. Braz J Microbiol 45: 67-75.

SREY S, JAHID IK AND HÁ SD. 2013. Biofilm formation in food industries: A food safety concern. Food Control 31: $572-585$.

STEPANOVIĆ S, VUKOVIĆ D, HOLA V, BONAVENTURA G, DJUKIĆ S, CIRKOVIĆ I AND RUZICKA F. 2007. Quantification of biofilm in microtiter plates: Overview of testing Conditions and practical recommendations for assessment of biofilm production by staphylococci. APMIS 115: 891-899.

VAUCHER RA, MOTTA AS AND BRANDELLI A. 2010. Evaluation of the in vitro cytotoxicity of the antimicrobial peptide P34. Cell Biol Int 34: 317-323.

YARON S AND RÖMLING U. 2014. Biofilm formation by enteric pathogens and its role in plant colonization and persistence. Microb Biotechnol 7: 496-516.

ZOBELL CE. 1943. The effect of solid surfaces upon bacterial activity. J Bacteriol 46: 39-56. 